\title{
HUBUNGAN MOTIVASI BELAJAR TERHADAP KINERJA SISWA DALAM PRAKTIKUM INSTALASI TENAGA LISTRIK DI KELAS XI TIPTL SMK N 3 SINGARAJA
}

\author{
M. S. Praja. Setiawan', I. P. Suka Arsa², G. Indrawan ${ }^{3}$ \\ 1,2Prodi Pendidikan Teknik Elektro, Universitas Pendidikan Ganesha, Singaraja \\ ${ }^{3}$ Teknik Elektronika, Universitas Pendidikan Ganesha, Singaraja \\ e-mail: praja_setiawan@yahoo.co.id, suka.arsa@undiksha.ac.id, gindrawan@undiksha.ac.id
}

\begin{abstract}
Abstrak
Penelitian ini bertujuan untuk mengetahui (1) hubungan motivasi belajar terhadap kinerja siswa dalam praktikum instalasi tenaga listrik pada siswa kelas XI TIPTL di SMK Negeri 3 Singaraja, (2) mengetahui tingkat motivasi belajar siswa pada mata pelajaran instalasi tenaga listrik program keahlian Teknik Instalasi Pemanfaatan Tenaga Listrik (TIPTL) kelas XI di SMK Negeri 3 Singaraja, dan (3) mengetahui tingkat kinerja siswa dalam praktikum instalasi tenaga listrik (TIPTL) pada siswa kelas XI program keahlian Teknik Instalasi Pemanfaatan Tenaga Listrik (TIPTL) di SMK Negeri 3 Singaraja. (4) untuk mengetahui hubungan kinerja siswa dalam praktikum instalasi tenaga listrik dengan motivasi siswa kelas XI TIPTL. Penelitian ini adalah penelitian korelasional. Sampel yang diteliti adalah siswa kelas XI TIPTLdengan jumlah sampel sebanyak 62 siswa. Variabel yang diteliti adalah dua variabel,variabel terikat, yaitu kinerja siswa dan satu variabel bebas, yaitu motivasi belajar. Data nilai kinerja diperoleh melalui lembar observasi, sedangkan untuk motivasi nilai diperoleh melalui penyebaran kuesioner, untuk mendapatkan penjelasan mengenai hubungan yang diberikan antar variabel penelitian dilakukan dengan menggunakan analisis teknik uji spearman rank dengan terlebih dahulu melakukan uji asumsi, yaitu uji normalitas, uji linieritas, dan uji heterokedastisitas. Hasil penelitian ini terdapat tingkat motivasi dengan rata-rata kelas sebesar $96,06 \%$ sedangkan untuk kinerja siswa dalam melakukan praktikum instalasi tenaga listrik pada siswa kelas XI di SMK Negeri 3 Singaraja diperoleh rata-rata kelas sebesar $69,95 \%$ dalam kategori sangat baik. Jadi dalam penelitian ini hubungan antara motivasi dengan kinerja siswa dalam pratikum instalasi tenaga listrik pada siswa kelas XI TIPTL di SMK Negeri 3 Singaraja dengan diperoleh koefisien korelasi sebesar 0,647 dengan nilai signifikasi sebesar 0,05 yang artinya arah korelasi positif dengan tingkat korelasi kuat, Bagi pihak guru SMK Negeri 3 Singaraja agar lebih membangkitkan motivasi siswa agar lebih mendukung proses belajar siswa sebagai upaya untuk meningkatkan kinerja siswa.
\end{abstract}

Kata kunci: Motivasi Belajar, Kinerja Siswa

\begin{abstract}
This study is aimed to determine (1) the relationship between learning motivation to the students' performance in the electric power installation practicum in the students of class XI TIPTL in SMK Negeri 3 Singaraja, (2) to know the level of students' motivation on the subjects of electric power installation expertise program of Installation Technique of Power Utilization Electricity class XI in SMK Negeri 3 Singaraja, and (3) to know the level of students' performance in electrical power installation practice in grade XI students of Electrical Power Installation Engineering program at SMK Negeri 3 Singaraja. (4) to know the relation of students' performance in electric power installation practicum with students' motivation of class XI TIPTL. This research is a correlational research. Samples studied were students of class XI TIPTL with number of samples are as many as 62 students. There are two variables studied which are dependent variable, that is students' performance and one independent variable, that is learning motivation. Performance value data was obtained through observation sheet, while for value motivation was obtained through questionnaire distribution, to get explanation about the relationship given between research variables was done by using spearman rank test technique by first performing assumption test, ie normality test, linearity test, and heterocedasticity test. The result of this research is motivation level with average grade 96,06\% while for students' performance in doing electric power installation at student of class XI in SMK Negeri 3 Singaraja obtained average class equal to $69,95 \%$ in very good category. So in this study the relationship between motivation and student performance in praktikum electrical installation on students of class XI TIPTL in SMK Negeri 3 Singaraja with correlation coefficient obtained by 0.647 with a significance value of which means the direction of positive correlation with a strong correlation level, for the theacher SMK Negeri 3 Singaraja to more motivation
\end{abstract}


students to better support the learning process of students as an effort to improve student performance.

Keywords: Motivation to learn, Student Performance.

\section{Pendahuluan}

Pesatnya pembangunan yang disertai dengan perkembangan IImu Pengetahuan dan teknologi dewasa ini perlu direspon oleh kinerja dunia pendidikan yang profesional dan memiliki mutu tinggi. Pembangunan di suatu negara sangat ditentukan oleh bagaimana negara itu memperlakukan pendidikan. Dunia pendidikan yang bermutu diharapkan dapat mendukung tercetaknya generasi-generasi pemuda penerus bangsa yang cerdas, terampil dan berwawasan luas sehingga mampu bersaing di era global. Karena pada hakikatnya fungsi pendidikan adalah untuk mengembangkan kemampuan serta meningkatkan mutu kehidupan dan martabat manusia (Undang-Undang Nomor 20 Tahun 2003). Keberhasilan pendidikan ditentukan oleh banyak aspek yang saling berkaitan. Secara falsafati, pendidikan adalah proses panjang dan berkelanjutan untuk mentranformasikan peserta didik menjadi manusia yang sesuai dengan tujuan penciptaanya, yaitu bermanfaat bagi dirinya, bagi sesama, bagi alam semesta, beserta segenap isi dan peradabannya.

Proses pendidikan yang baik adalah dengan memberikan kesempatan pada anak untuk kreatif. Itu harus dilakukan sebab pada dasarnya gaya berpikir anak tidak bisa diarahkan. Selain kurang kreatifnya para pendidik dalam membingbing siswa, kurikulum yang sentralistik membuat potret pendidikan semakin buram. Kurikulum hanya didasarkan pada pengetahuan pemerintah tanpa memperhatikankebutuhan masyarakat.

Disinilah guru merupakan pihak yang paling banyak berhubungan dengan proses belajar mengajar disekolah. Guru yang baik adalah guru yang peka terhadap perkembangan belajar dan prestasi anak didik di sekolah. Guru adalah orang yang terlibat langsung dalam kegiatan pembelajaran, sehingga dia dituntut untuk menelusuri berbagai kendala yang sedang dihadapi siswanya. Guru profesional memiliki pengetahuan yang luas serta dalam dari satuan pelajaran yang akan diajarkan serta penguasaan metodologi dalam arti memiliki pengetahuan berbagai metode dalam proses belajar mengajar.

Sekolah menengah kejuruan atau disebut SMK adalah bagian terpadu dari Sistem Pendidikan Nasional, yang mempunyai peranan penting di dalam menyiapkan dan pengembangan Sumber Daya Manusia dan memiliki tugas dan tanggung jawab dalam penyelenggaraan teknologi di dunia industri. SMK Negeri 3 Singaraja merupakan salah satu pendidikan formal program studi yang dimiliki salah satu dari mata diklat yaitu Instalasi Tenaga Listrik, Mata pelajaran ini diberikan kepada kelas XI dengan demikian permaslahan yang sering terjadi dalam proses belajar. Hasil belajar mencakup tiga ranah kognitif, psikomotorik, dan afektif. Kemampuan intelektual siswa menjadi tolak ukur keberhasilan dalam proses belajar pada ranah kognitif. Fokus pada ranah kognitif terlihat pada penekanan pada hasil ujian akhir baik semester maupun nasional, kebanyakan sekolah sebagai salah satu kriteria utama bonafiditas sekolah. Pencapaian hasil belajar pada ranah tersebut kemudian menjadi lebih menonjol dibandingkan dengan ranah yang lain. Pencapaian ranah kognitif ditentukan oleh banyak faktor baik eksternal maupun internal. Faktor eksternal merupakan faktor yang berasal dari luar, misalnya lingkungan keluarga, sekolah, masyrakat, dan waktu. Faktor tersebut berpengaruh terhadap hasil belajar melalui perannya dalam mempengaruhi orientasi dan kondisi internal seorang. Faktorinternal merupakan faktor yang berasal dari diri seseorang. Faktor Internalyang mempengaruhi hasil belajar kognitif dapat dikelompokan kedalam faktor biologis dan psikologis. Faktor biologis mencangkup kondisi kecacatan fisik dan kesehatan fisik. Faktor psikologis mencangkup intelegensi, kemauan, bakat, daya ingat, daya konsentrasi menurut faktor internaldiketahui lebih dominan dalam menentukan hasil belajar dibandingkan dengan faktor lingkungan dalam mempengaruhi salah satu faktor internal yang memilki pengaruh kuat tehadap hasil belajaradalah motivasi.

Jadi motivasi merupakan pendorong kinerja yang baik di pengaruhi beberapa faktor banyak teori yang dikemukakan berkaitan dengan kinerja. Model kinerja merupakan fungsi 
dari interaksi perkalian antara motivasi dan kecakapan, sehingga jika seseorang rendah pada salah satu komponennya maka kinerjanya akan rendah pula. Oleh karena itu peneliti mengambil judul "Hubungan Motivasi Belajar Terhadap Kinerja Siswa Dalam Praktikum Instalasi Tenaga Listrik Pada Siswa Kelas XI TIPTL Di SMK Negeri 3 Singaraja."

Berdasarkan latar belakang permasalahan diatas, maka rumusan permasalahan yang diajukan dalam proposal ini adalah apakah hubungan antara kinerja siswa pada instalasi tenaga listrik dan perbandingan yang didapat dari hasil motivasi siswa yang dimilki akan berpengaruh kepada Kelas XI TIPTL SMK Negeri 3 Singaraja mempengaruhi hasil kinerja untuk mengetahui kemampuan kognitifnya

Dari latar belakang masalah dan berbagai permasalahan yang telah di identifikasi diatas maka perlu adanya pembatasan masalah dalam penelitian ini pembahasan masalah hanya mencangkup apakah dengan penerapan model pembelajaran lain yang digunakan berpengaruh dalam hubungan antara kinerja siswa dalam praktikum instalasi tenaga listrik terhadap motivasi siswa.

Dalam pencapaian pembelajaran teori merakit Instalasi tenaga listrik menjadikan siswa mampu menghasilkan kinerja siswa dalam pelajaran Instalasi tenaga listrik : 1) Berapakah tingkat motivasi belajar siswa kelas XI TIPTL di SMK Negeri 3 Singaraja ?, 2) Berapakah tingkat kinerja siswa dalam praktikum instalasi tenaga listrik pada siswa kelas XI TIPTL di SMK Negeri 3 Singaraja?, 3) Apakah terdapat hubungan antara motivasi belajar dengan kinerja siswa dalam praktikum instalasi tenaga listrik pada siswa kelas XI TIPTL Di SMK Negeri 3 Singaraja.

Hasil penelitian ini diharapkan dapat memberikan beberapa manfaat, sebagai berikut.

1) Bagi peneliti, hasil penelitian ini diharapkan dapat berguna dalam menambah wawasan pengetahuan dalam bidang penelitian dan untuk mengetahui Untuk mengetahui hubungan antara kinerja siswa dalam praktikum instalasi tenaga listrik dengan motivasi belajar siswa kelas XI TIPTL di SMK Negeri 3 Singaraja, 2) Bagi Guru dapat menambah wawasan tentang hubungan pencapaian pembelajaran kognitif siswa dalam pratikum, 3) Bagi siswa agar dapat menghasilkan kinerja yang baik dalam praktikum dan menumbuhkan motivasi yang dimilikinya.

Peneliti membahas variabel penelitian secara konseptual dari berbagai teori atau konsep dari para ahli. Kajian konseptual dari berbagai teori atau konsep dari para ahli. Kajian konseptual ini dimulai dari variabel terikat $(Y)$ dilanjutkan dengan pembahasan variabel $(X)$. Kajian teoritis tidak sekedar mencantumkan teori-teori secara runtut dari berbagai sumber, tetapi hasil analisis dari berbagai teori. Setelah menganalisis, kemudian dilanjutkan dengan membandingkan antar teori untuk menemukan persamaan dan perbedaan.

Whitmore (dalam Uno, 2012:59-60), secara sederhana mengemukakan kinerja adalah pelaksana fungsi-fungsi yang dituntut dari seseorang. Pengertian kinerja yang dianggapnya representatif, maka tergambarnya tanggung jawab yang besar dari pekerjaan seseorang.

Kinerja adalah keadaan atau tingkat prilaku seseorang yang harus dicapai dengan persyaratan tertentu. Sementara itu, dengan kalimat yang senada, Bernandin dan Russel menyatakan. Istilah kinerja dengan performasi adalah sejumlah catatan yang dihasilkan dari fungsi suatu pekerjaan tertentu atau kegiatan selama suatu periode waktu tertentu.

Penilaian kinerja merupakan penilaian yang dilakukan dengan mengamati kegiatan siswa dalam melakukan sesuatu. Penilaian ini cocok digunakan untuk menilai ketercapaian kompetensi yang menuntut siswa melakukan tugas tertentu seperti: praktik di laboratorium, praktik sholat, praktik olahraga, presentasi, diskusi, bermain peran, memainkan alat musik, bernyanyi, membaca puisi atau deklarasi dan lain-lain.

Variabel independen sering disebut sebagai variabel stimulus, prediktor antecedent. Dalam bahasa Indonesia sering disebut sebagai variabel bebas Variabel bebas merupakan variabel yang mempengaruhi atau yang menjadi sebab perubahannya atau timbulnya variabel terikat. Motivasi menurut Mc Donald (dalam Sadirman, 2005:73), Motivasi adalah suatu perubahan yang ada pada diri manusia yang menyebabkan munculnya energi pada diri manusia, sehingga akan adanya dorongan dalam persoalan gejala kejiwaan, perasaan dan juga emosi, untuk kemudian bertindak atau melakukan sesuatu. Hal ini disebabkan adanya faktor kebutuhan atau keinginan. 
Menurut Sardiman (2005:84-85) menyatakan Fungsi Motivasi memberi sebuah dorongan usaha dan capaian prestasi seseorang melakukan sesuatu usaha karena adanya motivasi yang baik dalam belajar akan memberikan hasil yang baik. Dengan kata lain, dengan adanya usaha yang tekun dan didasari adanya motivasi, maka seseorang yang belajar itu akan dapat melahirkan prestasi yang baik.

Sardiman, A.M. (2011:91) Menjelaskan didalam kegiatan belajar-mengajar peranan motivasi baik intrinsik maupun ekstrinsik sangat diperlukan. Dengan Motivasi, seorang pelajar dapat mengembangkan aktivitas dan inisiatif, dapat mengarahkan dan memelihara dalam melakukan kegiatan belajar. Instalasi penerangan adalah suatu rangkaian beberapa komponen listrik dari sumber ke beban yang saling berhubungan satu sama lainnya secara listrik, yang terletak pada suatu tempat atau ruangan tertentu.

Penelitian korelasional menggambarkan suatu pendekatan umum untuk penelitian yang berfokus pada penafsiran pada kovariasi diantara variabel yang muncul secara alami. Tujuan penelitian korelasional adalah untuk mengidentifikasi hubungan prediktif dengan menggunakan teknik korelasi atau teknik statistik yang lebih canggih. Menurut Gay (dalam Emzir, 2012:37), penelitian korelasional kadang-kadang diperlakukan sebagai penelitian deskriptif, terutama disebabkan penelitian korelasional mendeskripsikan sebuah kondisi yang telah ada. Tingkat hubungan diungkapkan sebagai suatu koefisien korelasi. Jika terdapat hubungan antara dua variabel, maka itu berarti bahwa skor didalam rentangan tertentu pada suatu pengukuran berasosiasi dengan skor didalam rentangan tertentu pada pengukuran yang lain. Tujuan studi korelasional adalah untuk menentukan hubungan antara variabel, atau untuk menggunakan hubungan tersebut untuk membuat prediksi. Penelitian korelasional menggunakan instrumen untuk menentukan apakah, dan untuk tingkat apa, terdapat hubungan antara dua variabel atau lebih yang dapat dikuantitatifkan.

Tujuan penelitian korelasional menurut Suryabrata, adalah untuk mendeteksi sejauh mana variasi-variasi pada suatu faktor berkaitan dengan variasi-variasi pada satu atau lebih faktor lain berdasarkan pada koefisien korelasi.

\section{Metode}

Tempat untuk melaksanakan penelitian ini adalah di SMK Negeri 3 Singaraja yang berda tepatnya Jl. Gempol, Banyuning, Kec, Buleleng, Kabupaten Buleleng, Bali 81112, Indonesia. Jenis penelitian ini adalah penelitian korelasional, yaitu penelitian yang berusaha untuk menentukan apakah, dan untuk tingkat apa, terdapat hubungan antara dua atau lebih variabel yang dapat dikuantitatifkan. Tingkat hubungan diungkapkan sebagai suatu koefisien korelasi.

Penelitian korelasional menggunakan instrumen untuk menentukan apakah, dan untuk tingkat apa, terdapat hubungan antara dua variabel atau lebih yang dikuantitatifkan. Pada dasarnya penelitian korelasional melibatkan perhitungan korelasi antara variabel yang komplek (variabel kriteria) dengan variabel lain yang diaangap mempunyai hubungan (variabel prediktor). Adapun prosedur dalam penelitian ini adalah sebagai berikut.

1) Mengidentifikasi adanya permasalahan yang signifikan untuk dipecahkan melalui metode deskriptif., 2) Merumuskan dan membatasi permasalahan, 3) Menentukan tujuan dan manfaat penelitian, 4) Melakukan studi pustaka yang berkaitan dengan permasalahan penelitian, 5) Mendesain metode penelitian yang akan digunakan termasuk dalam hal ini adalah menentukan populasi, sampel, teknik sampling, teknik pengumpulan data, instrumen penelitian, dan analisis data. Dalam proses penyusunan instrumen penelitian yang dilakukan pertama, yaitu menggali informasi dengan cara melakukan observasi terhadap beberapa siswa terkait dengan kinerja saat yang akan dijadikan acuan dalam penentuan indikator pernyataan pada instrumen penelitian. Menyusun instrumen motivasi belajar berupa kuesioner, 6) Uji coba instrumen. Sebelum penyebaran kuesioner dan lembar pengamatan dilakukan pada kelompok sampel, peneliti melakukan uji coba tes dan lembar pengamatan dengan menyebarkan tes pada kelompok kecil. Hal ini dilakukan untuk mendapatkan gambaran empirik apakah seluruh instrumen sudah dimengerti oleh responden dan layak digunakan, 7) Pengambilan data dengan menyebarkan tes dan lembar pengamatan pada sampel penelitian. Tes disebarkan pada anggota sampel untuk mendapatkan datapenelitian, 8) Menganalisis data. Hasil tes dan lembar pengamatan dalam penelitian ini dianalisis secara 
kuantitatif untuk kemudian dideskripsikan secara kualitatif, 9) Membuat laporan penelitian.

Menurut Sugiyono (2015:117), populasi adalah wilayah generalisasi yang terdiri dari atas obyek atau subyek yang merupakan kualitas dan karakteristik tertentu yang ditetapkan oleh peneliti untuk dipelajari dan kemudian ditarik kesimpulannya. Populasi dalam penelitian ini adalah seluruh siswa kelas XI Kompetensi Keahlian Teknik Instalasi Pemanfaatan Tenaga Listrik SMK Negeri 3 Singaraja tahun ajaran 2017/2018 yang berjumlah 62 siswa.

Menurut sugiyono (2015:118), sampel adalah bagian dari jumlah dan karakteristik yang dimiliki oleh populasi tersebut.

Teknik pengumpulan data merupakan langkah yang paling utama dalam penelitian, karena tujuan utama dari penelitian ini adalah mendapatkan data. Kinerja adalah skor yang didapat dari gambaran hasil kerja yang dilakukan seseorang, atau dengan kata lain kinerja adalah unjuk kerja seseorang yang diperoleh melalui instrumen pengumpulan data tentang kinerja seseorang.

Lembar pengamatan aspek afektif digunakan untuk mengukur dan menilai tingkat apresiasi siswa terhadap pembelajaran yang dilaksanakan. Lembar pengamatan kinerja dalam penelitian ini terdiri dari atas 20 aspek/indikator yang dimodifikasi dari Sapinatulbahriah (2011) serta ditetapkan dengan rentang penilaian dalam bentuk skala penilaian, yaitu sangat baik, cukup baik, baik, dan kurang.

Validitas adalah suatu ukuran yang menunjukan tingkat suatu instrument (Arikunto, 2006:168). Sebuah instrumen dikatakan valid apabila mampu mengukur apa yang diinginkan dan dapat mengungkap data dari variabel yang diteliti secara tepat, dalam hal ini validitas yang digunakan adalah validitas konstruk karena instrumen yang digunakan berupa lembar pengamatan. Instrumen tersebut diujicobakan pada sampel dari mana populasi diambil. Jumlah anggota sampel yang digunakan sebanyak 33 siswa.

Selanjutnya untuk mengetahui validitas butir, koefisien korelasi Product Momment $\left(r_{\mathrm{xy}}\right)$ dibandingkan dengan harga $r_{\text {tabel. }}$. Jika $r_{x y}>r_{\text {tabel }}$ maka terdapat korelasi yang signifikan antara skor butir dengan skor total yang artinya butir bersangkutan dinyatakan valid. Sebaliknya jika $r_{x y} \leq r_{\text {tabel }}$ maka butir tersebut dinyatakan tidak valid. Perhitungan uji validitas dilakukan dengan bantuan program Microsoft Office Excel.

Uji reliabilitas instrumen dimaksudkan untuk mengetahui keajegan instrumen dalam mengumpulkan data penelitian. Suatu instrumen dikatakan reliabel jika instrument tersebut ketika dipakai untuk mengukur suatu gejala yang sama dalam waktu yang berlainan akan menunjukan hasil yang sama. Dalam menguji reliabilitas instrumen dipergunakan rumus Alpha Cronbach. Pada prinsipnya meneliti adalah melakukan pengukuran, maka harus ada alat ukur yang baik. Alat ukur dalam penelitian biasanya dinamakan instrumen peneliti.

Menurut Sugiyono (2014:199), mengemukakan bahwa kuesioner merupakan teknik pengumpulan data yang dilakukan dengan cara memberi seperangkat pertanyaan atau pernyataan tertulis kepada responden untuk dijawabnya. Kuesioner merupakan teknik pengumpulan data yang efisien bila peneliti tahu dengan pasti variabel yang akan diukur dan tahu apa yang bisa diharapkan dari responden.

Instrumen yang digunakan untuk pengambilan data motivasi belajar siswa pada pelajaran Instalasi Tenaga Listrik adalah pedoman observasi dan kuesioner. Indikator motivasi belajar yang digunakan. Adapun hal-hal yang penting dalam motivasi belajar adalah

1) ketekunan dalam belajar, 2) ulet dalam menghadapi kesulitan, 3) minat dan ketajaman perhatian dalam belajar, 4) berprestasi dalam belajar, dan 5) mandiri dalam belajar.

Kuesioner digunakan untuk mendapatkan informasi pendukung mengenai motivasi belajar. Sebelum melakukan uji coba angket dengan 30 pernyataan. Pengujian validitas setiap butir pernyataan pada kuesioner digunakan analisis item, yang mengkorelasikan skor tiap butir pernyataan dengan skor total yang merupakan jumlah setiap skor butir pernyataan. Uji validitas dalam penelitian ini dilakukan dengan menggunakan teknik Product Moment (Pearson's Correlation) dengan bantuan program IBM SPSS 24.0 for Windows.

Sebelum data-data penelitian diuji hipotesisnya, terlebih dahulu akan dilakukan uji prasyarat analisis. Uji prasyarat yang akan digunakan adalah uji normalitas, uji linieritas dan regresi, dan uji heterokedastisitas. Uji normalitas sebaran data perlu dilakukan karena data yang diambil dalam penelitian ini adalah sampel, sehingga dari uji normalitas sebaran ini akan 
diketahui normal tidaknya penyebaran variabel tersebut. Uji normalitas dalam penelitian ini akan menggunakan bantuan program SPSS.

Uji linieritas dilakukan untuk mengetahui bentuk hubungan antara variabel terikat dengan variabel bebas. Perhitungan dilakukan dengan bantuan komputer program SPSS. Dalam kaitanya dengan kehidupan sehari-hari, misalnya dalam bidang ekonomi, terkadang kita ingin mengetahui bagaimana hubungan, faktor-faktor, gangguan atau hambatan serta pengaruh apa saja yang terjadi dalam proses kegiatan ekonomi yang kita lakukan.

Uji heterokedastisitas digunakan untuk mengetahui ada atau tidaknya penyimpangan asumsi klasik heteroskedastisitas, yaitu dengan ketidaksamaan varian dari residual untuk semua pengamatan pada model regresi. Hipotesis statistik yang digunakan untuk menguji hubungan dinyatakan, sebagai berikut. Hipotesis statistik yang digunakan untuk menguji hubungan dinyatakan, sebagai berikut.

$\mathrm{H}_{0}: \rho=0$ (tidak terdapat hubungan)

$\mathrm{Ha}: \rho \neq 0$ (terdapathubungan)

Hipotesis yang diuji pada penelitian ini adalah hubungan antara motivasi belajar dengan kinerja siswa dalam praktikum instalasi tenaga listrik pada siswa kelas XI TIPTL Di SMK Negeri 3 Singaraja.

$\mathrm{H}_{0}$ : tidak ada hubungan hubungan antara motivasi belajar dengan kinerja siswa dalam praktikum instalasi tenaga listrik pada siswa kelas XI TIPTL Di SMK Negeri 3 Singaraja.

Ha: ada hubungan hubungan antara motivasi belajar dengan kinerja siswa dalam praktikum instalasi tenaga listrik pada siswa kelas XI TIPTL Di SMK Negeri 3 Singaraja

Dimana :

$\rho_{y . x} \neq 0=$ koefisien korelasi antara hubungan antara motivasi belajar dengan kinerja siswa, yang berlaku untuk populasi siswa pada program keahlian Teknik Instalasi Pemanfaatan tenaga listrik di SMK Negeri 3 Singaraja.

\section{HASIL DAN PEMBAHASAN}

Pada bagian ini disajikan hasil penelitian hubungan motivasi belajar terhadap siswa dalam pratikum instalasi tenaga listrik. Sebelum uji hipotesis dilakukan, terlebih dahulu dilakukan uji prasyarat analisis, yaitu uji asumsi klasik. Terdapat tiga uji prasyarat yang dilakukan dalam penelitian ini, yaitu uji normalitas sebaran data, uji linieritas hubungan dan keberartian arah regresi, dan uji heteroskedastisidas. Uji Normalitas bertujuan untuk menguji apakah sebaran data variabel terikat dan variabel bebas mempunyai distribusi normal atau tidak normal. Uji normalitas bertujuan untuk menguji apakah sebaran data variabel terikat dan variabel bebas mempunyai distribusi normal atau tidak normal.

Deskripsi hasil data penelitian mencakup hasil analisis deskriptif meliputi skor rata-rata, skor minimum, skor maksimum,rentang, simpangan baku, median, modus, dan kategorisasi masing-masing variabel yang diteliti. Hasil uji deskriptif tersebut menggunakan bantuan program SPSS 24.0 for Windows. Deskripsi data variabel motivasi dan kinerja siswa tersaji pada Tabel.

Tabel 1. Hasil Analisis Deskriptif Variabel Motivasi $(X)$ dengan Kinerja Siswa $(Y)$

$\begin{array}{lcc}\begin{array}{c}\text { Statistik } \\ \text { Deskriptif }\end{array} & \text { Motivasi }(X) & \begin{array}{c}\text { Kinerja Siswa } \\ (Y)\end{array} \\ \text { Skor rata-rata } & 96,06 & 69,95 \\ \text { Median } & 96 & 70 \\ \text { Modus } & 90 & 69 \\ \text { Simpangan baku } & 7,03 & 3,65 \\ \text { Rentang } & 26 & 20 \\ \text { Skor minimum } & 84 & 58 \\ \text { Skor maksimum } & 110 & 78\end{array}$

Sumber:Output SPSS 24.0 for Windows 
Berdasarkan Tabel dapat diketahui bahwa motivasi dengan kategori sangat baik sebanyak 19 orang $(30,65 \%)$ dan kategori baik sebanyak 43 orang $(69,35 \%)$, sedangkan tidak ada responden yang termasuk dalam kategori cukup, kurang, dan sangat kurang. Jadi, sebagian besar siswa memiliki motivasi yang baik dengan frekuensi 43 (69,35\%).

Data hasil penelitian mengenai kinerja siswa tersebut kemudian disajikan dalam bentuk tabel distribusi frekuensi untuk mempermudah tahap analisis selanjutnya.

Tabel 2. Kategori Data Motivasi Siswa

\begin{tabular}{clcc}
\hline Interval & \multicolumn{1}{c}{ Kategori } & $\begin{array}{c}\text { Frekue } \\
\text { nsi }\end{array}$ & $\begin{array}{c}\text { Present } \\
\text { ase }\end{array}$ \\
\hline $100 \leq \mathrm{x}$ & Sangat Baik & 19 & $30,65 \%$ \\
\hline $\begin{array}{c}83,33 \leq \mathrm{x}< \\
100\end{array}$ & Baik & 43 & $69,35 \%$ \\
\hline $\begin{array}{c}66,67 \leq \mathrm{x}< \\
83,33\end{array}$ & Cukup & 0 & $0,00 \%$ \\
\hline $50 \leq \mathrm{x}<66,67$ & Kurang & 0 & $0,00 \%$ \\
\hline $\mathrm{x}<50$ & Sangat Kurang & 0 & $0,00 \%$ \\
\hline & Jumlah & 62 & $100,00 \%$ \\
\hline
\end{tabular}

Tabel 3. Hasil Uji Normalitas Sebaran Data

\begin{tabular}{ccccl}
\hline Variabel & \multicolumn{3}{c}{ Kolmogorov-Smirnov } & Keterangan \\
\hline & Statistic & $d f$ & Sig. & \\
\hline Motivasi & 0,099 & 62 & 0,200 & $\begin{array}{l}\text { Berdistribusi } \\
\text { normal }\end{array}$ \\
\hline $\begin{array}{c}\text { Kinerja } \\
\text { Siswa }\end{array}$ & 0,107 & 62 & 0,075 & $\begin{array}{l}\text { Berdistribusi } \\
\text { normal }\end{array}$ \\
\hline
\end{tabular}

Berdasarkan Tabel diatas ditunjukkan bahwa nilai sig. statistik Kolmogorov-Smirnov untuk variabel motivasi sebesar 0,200 dan variabel kinerja sebesar 0,075. Nilai sig. tersebut lebih besar dari 0,05 untuk statistik Kolmogorov-Smirnov. Berdasarkan kriteria uji normalitas, sebaran data terdistribusi normal jika nilai sig. lebih besar dari 0,05. Hal ini menunjukkan bahwa sebaran data motivasi dan kinerja siswa berdistribusi normal.

Uji linieritas garis regresi dimaksudkan untuk memprediksi atau menguji pengaruh satu variabel bebas terhadap variabel terikat.

Tabel 4. Hasil Uji Linieritasdan Keberartian Arah Regresi

\begin{tabular}{crrlrr}
\hline Model & $\begin{array}{c}\text { Sum } \\
\text { of Squares }\end{array}$ & $d f$ & $\begin{array}{l}\text { Mean } \\
\text { Square }\end{array}$ & F & Sig. \\
Regression & 341,073 & 1 & 341,073 & 43,194 & 0,000 \\
Residual & 473,782 & 60 & 7,86 & & \\
Total & 814,855 & 61 & & & \\
\hline
\end{tabular}

Berdasarkan Tabel diatas terlihat bahwa nilai $F_{\text {hitung }}$ sebesar 43,194 dengan tingkat 
signifikansi atau probabilitas 0,000lebih kecil dari 0,05 maka model regresi dapat dipakai untuk memprediksikan variabel terikat (kinerja siswa).Uji heteroskedastisitas merupakan salah satu bagian dari uji asumsi dalam model regresi. Berdasarkan Tabel diatas diketahui bahwa nilai signifikansi antara variabel bebas dengan absolut residual (ABS) 0,061 lebih besar dari 0,05. Jadi, dapat disimpulkan bahwa model regresi yang digunakan tidak terdapat adanya heteroskedastisitas. Setelah uji prasyarat terpenuhi maka akan dilanjutkan dengan uji hipotesis untuk menjawab permasalahan penelitian

Tabel 5. Hasil Korelasi Product Moment

\begin{tabular}{lccc}
\hline & \multicolumn{2}{c}{ Correlations } & \\
\hline \multirow{2}{*}{ Motivasi } & Motivasi & Kinerja \\
\cline { 2 - 4 } & Pearson Correlation & 1 & 0,647 \\
\cline { 2 - 4 } & Sig. (2-tailed) & 62 & 0,000 \\
\cline { 2 - 4 } Kinerja & PearsonCorrelation & 0,647 & 1 \\
& Sig. (2-tailed) & 0,000 & 62 \\
\cline { 2 - 4 } & $\mathrm{N}$ & 62 & 62
\end{tabular}

Berdasarkan Tabel diatas ditunjukkan bahwa besar korelasi antara motivasi dengan kinerja siswa adalah 0,647 dengan nilai signifikansi 0,000. Nilai signifikan tersebut lebih kecil dari 0,05 , sehingga $\mathrm{H}_{0}$ ditolak dan $\mathrm{H}_{\mathrm{a}}$ diterima. Dengan demikian, terdapat hubungan antara motivasi dengan kinerja siswa dalam praktikum instalasi tenaga listrik pada siswa kelas $\mathrm{XI}$ TIPTL di SMK Negeri 3 Singaraja, dengan nilai koefisien korelasi sebesar 0,647 dengan arah koefisien positif dan tingkat korelasikuat.

Berdasarkan hasil analisis menggunakan korelasi product momentdiperoleh nilai koefisien korelasi sebesar 0,647 dengan kategori kuat dan arah pola positif. Pola positif menunjukkan bahwa semakin tinggi motivasi siswa, maka semakin tinggi juga kinerja siswa.Nilai signifikansi korelasi sebesar 0,000lebih kecil dari 0,05, sehingga terdapat korelasi yang signifikan antara motivasi dengan kinerja siswa praktikum instalasi tenaga listrik pada siswa kelas XI TIPTL di SMK Negeri 3 Singaraja.Dilihat dari hasil kuesioner motivasi diperoleh kecenderungan nilai rata-rata sebesar $96,06 \%$. Tingkat motivasi siswa yang termasuk dalam kategori baik tersebut menunjukkan adanya dorongan yang tinggi pula dalam diri mereka untuk berprestasi.

\section{Simpulan dan Saran}

Berdasarkan hasil penelitian dan pembahasaan dapat disimpulkan sebagai berikut. 1) Tingkat motivasi siswa kelas XI TIPTL di SMK Negeri 3 Singaraja diperoleh rata-rata kelas sebesar $96,06 \%$ dalam kategori baik, 2) Tingkat kinerja siswa dalam praktikum instalasi tenaga listrik pada siswa kelas XI TIPTL di SMK Negeri 3 Singaraja diperoleh rata-rata kelas sebesar $69,95 \%$ dalam kategori sangat baik, 3) Terdapat hubungan antara motivasi dengan kinerja siswa dalam praktikum instalasi tenaga listrik pada siswa kelas XI TIPTL di SMK Negeri 3 Singaraja dengan diperoleh koefisien korelasi sebesar 0,647 dengan nilai signifikansi sebesar 0,000 lebih kecil dari 0,05 yang artinya arah korelasi positif dengan tingkat korelasi kuat.

Berdasarkan hasil, pembahasan, dan simpulan, maka saran yang diajukan dalam penelitian ini adalah 1) Bagi pihak guru SMK Negeri 3 Singaraja agar lebih membangkitkan motivasi siswa agar lebih mendukung proses belajar siswa sebagai upaya untuk meningkatkan kinerja siswa, karena penelitian ini membuktikan bahwa terdapat hubungan antara motivasi dengan kinerja siswa, 2) Bagi peneliti selanjutnya yang tertarik untuk mengkaji aspek yang serupa mengenai hubungan antara motivasi dengan kinerja siswa diharapkan untuk mengembangkan penelitian ini dengan menggunakan populasi dan sampel yang lebih luas, 
tidak hanya di SMK Negeri 3 Singaraja, tetapi juga di sekolah lainnya agar hasil penelitian lebih teruji keandala.

\section{DAFTAR PUSTAKA}

Arikunto, S. 2006. Dasar-Dasar Evaluasi Pendidikan. Jakarta: Bumi Aksara.

Hamzah B. Uno, M.Pd, Prof. Dr \& Dr. Nina Lamatenggo, S.E.,M.Pd, 2012, Teori Kinerja dan Pengukurannya. Jakarta: PT Bumi Aksara.

Sardiman, A.M, 2005, Interaksi dan Motivasi Belajar Mengajar. Jakarta: PT Raja Grafindo Persada.

Sadirman,A.M, 2012, Interaksi \& Motivasi Belajar Mengajar. Jakarta: Rajawali Pers.

Sugiyono. Prof. Dr, .2015. Metode penelitian Pendidikan Pendekatan Kuantitatif, Kualitatif, dan R\&D. Bandung: CV Alfabeta.

Sugiyono, Prof. Dr, 2014, Metode Penelitian Pendidikan Pendekatan Kuantitatif, Kualitatif, dan $R \& D$. Bandung: CV Alfabet 